\title{
Innovation Approach to Environment Problems Solution at Coal Producers of the Far Eastern Federal District (FEFD)
}

\author{
Krupskaya L. T. ${ }^{1,2}$, Zvereva V. P. ${ }^{3,4}$, Morin V.A. ${ }^{2,}$ \\ Gul L.P. ${ }^{2}$, and Volobueva N.G. ${ }^{5}$, Golubev D.A. ${ }^{1,2}$ \\ ${ }^{1}$ Pacific National University, 136, Tikhookeanskaya str, \\ Khabarovsk, 680035, Russian Federation \\ ${ }^{2}$ Far East Scientific-Research Institute of Forestry, 71, \\ Volochaevskaya str, Khabarovsk, 680020 Russian
} Federation

\begin{abstract}
Based on the analysis of the processes of coal deposits development in FEFD, including development and mining operations, coal processing, reproduction of land productivity in technogenic formations (reclamation) and ecosystems rehabilitation, as well as regulatory framework it was concluded that innovation ways of solving environmental problems should be based on the monitoring and management of the environment quality. The innovative approach to environmental problems in the mining industry was set up on the basis of the authors' own research and publications of the Russian and foreign scientists, in terms of achieving harmony in sociobiotehnosfere, namely to use the potential of biological objects.
\end{abstract}

Keywords-environmental problems, innovation approach, environment, monitoring, productivity, reclamation

\section{INTRODUCTION}

In the short term it is expected to enhance the role of coal in the fuel and energy balance of Russia, as shown in the main principles of "Energy strategy of Russia's development until 2020". Intensive coal producers development is inevitably connected with a high technogenic load on the environment related to the constant increase of the volumes of waste treatment, which leads to negative environment changes. Socioeconomic level and health of the population of the region are largely determined by the most relevant environmental problems caused not only by accumulation of mining wastes, and air and water pollution, but also by growth of disturbed lands area. Therefore, the aim of the research was to use an innovative approach for solving environmental problems in coal enterprises of FEFD to ensure their environmental and social security. In terms of these aims the following tasks were determined: 1.To analyze, summarize and systematize the available literature sources, holdings, results of domestic and foreign patent research; 2 . To identify the sources of the environment contamination and assess their impact on the environment; 3 . To analyze the regulatory and legal framework; 4. To develop the measures for decreasing the negative impact of coal mining on environment using an innovative approach.

\author{
${ }^{3}$ Far East Federal University, 8, Sukhanova str, \\ Vladivostok, 690091, Russian Federation \\ ${ }^{4}$ Far East Geological Institute FEB RAS, 159, Prospect \\ 100 let Vladivostoka, Vladivostok, 690022, Russian \\ Federation \\ ${ }^{5}$ Northeastern State University, 13, Portovaya st, Magadan, \\ 685000, Russian Federation
}

\section{OBJECTS AND METHODS OF RESEARCH}

The objects of research were natural - mining systems. The subject was a set of ecological factors which have a negative impact on the environment. The methodological basis was the theory of academician V. I. Vernadsky [1] about biosphere and noosphere and the guidelines in the Programme and Methods of Technogene Biogeocoenoses study by B.P. Kolesnikov and L.V. Motorina [2]. The nature of the tasks solution predetermined to use the following essential methods to carry out certain research studies: 1 . Systematization of domestic, foreign literature, patent information, archived data of coal enterprises, normative-legal documents; 2 . Field investigations with geochemical profiles laying; 3. Landscape-geographical, traditional physico-chemical, chemical and biological (using test systems) methods; 4. Scientific forecasting; 5. Systematization and scientific classification. The main and determinative method of research is the systematiccomplex method.

\section{RESULTS AND DISCUSSION}

The current studies of this problem in our country and the region of research show that there are almost no publications providing constructive critical assessment of the practical use of technologies for coal deposits development [3-12]. In the FEFD special studies of the development of theoretical bases of environmental solutions, using innovative approach have not yet been carried out. It is known [3, etc.], that the exploitation of coal deposits is associated with the accumulation of significant amounts of waste having a negative impact on the state of air and water, plants and animal life, ultimately, on the health of population. According to the results of complex assessment of the environment state of the coal producers impact zones a very high degree of environmental stress was revealed there. To address environmental problems in the coal enterprises, for example, the reclamation of disturbed lands, there is a need to improve its legislative-regulatory framework.

Thus, the conditions of land productivity reproduction, defined by the current legislation of the Russian Federation, suppose no difference between geographical zones of the country, socio-economic conditions of the 
regions, environment conditions and forms of economic activity in the territories. The aim and tasks were set without concretization of the boundary and objects of activities. Unfortunately, the phrase "return the land to a condition suitable for forest management" does not define either the remediation works, nor their quality when making the contracts of forest land lease for mining. The transfer of land under the overgrowth as the method of disturbed lands reclamation is not defined by normative and/or legal acts of the Russian Federation and is used by default. The requirements to afforestation on reclaimed lands require the creation of artificial forest plantations, but do not define either a source of funding, or the performer of the work. Based on the above, the reclamation of disturbed lands and their return to the State Forest Fund is currently being carried out with substantial deviations from the requirements to the scope and quality of remediation according to the present legislation of Russian Federation. At present it should be considered that in FEFD remediation is inadequately provided with instructive-methodical documents. For each administrative territory of FEED, where mining is carried out, the specialized instructions, methods or guidelines defining the structure, directions, methods, and technologies for remediation have not been yet approved by the authorized bodies. A general and fundamental drawback of existing instructions, methods and guides is their focus on rehabilitation of disturbed lands, local sections of damaged land and some technogenic bodies within the rented land allotment. But the natural-climatic conditions of the environment, and above all, environment visual characteristics and features, and interaction of shapes, size and orientation of the technogenic elements and systems are not considered. The measures to ensure the conditions for resumption of the land and water fauna have not been practically implemented. There are no guidelines for optimization and restoration of watercourse channels, their water protection zones (up to $200 \mathrm{~m}$ ) and shoreline protective belts (up to $50 \mathrm{~m}$ ) [6], which, in fact, are the "center" around and along which the areas subject to disturbed lands reclamation should be formed. It should be noted that in other countries the works ensuring stabilization of channel processes, water pollution reducing, creating habitats for fish fauna restoring, are widespread and routine activities for reclamation of disturbed lands. Also the arrangement of areas for migration of animals who are isolated by disturbed impassable land masses from the access both to the valley bottom and to the opposite slopes is also not made. It is necessary to create the so-called, passages for reindeer herds running in many-kilometer technogenic masses, that can help to improve the environmental significance of reclaimed land. It is well known that to reduce the negative impact of coal mining it is necessary to develop the effective measures for prevention of negative anthropogenic impact on natural system as a whole and its components in particular. The environmental problems escalated in the 21st century, including mining, cannot be solved by previously used traditional methods. So, the demand arose to develop and implement the innovative methods and technologies, in which the target application of biological systems and the processes in various spheres of activity, including mining, is put into practice. One of the relevant aspects of this problem solution is to develop nature-friendly biotechnology in mining, which is based on the use of the biological potential of the living organisms (plants, animals, microorganisms) and their parts (cells, enzymes). Its use will lead to the "industrial metabolism", to analyze the material flows, involved by a man in the technogenesis scope, match to the natural biosphere cycle by creating industrial biochemical cycles involving micro-organisms, plants, animals, i.e., to develop a new direction - environmental biotechnology [11], to arrange a comprehensive and rational use of natural resources, similar to natural processes of circulation to solve the problems of the environment protection from industrial wastes. The present stage of scientific and technological progress is characterized by revolutionary changes in biology. Biology as a scientific basis of biological processes and systems made a huge leap over the past few decades 12]. It came out on top of the contemporary natural science, at the molecular and sub cellular level. The future application of the biological potential of living organisms in mining is promising, as the planet's natural resources are exhausted, and it is necessary to maintain the sustainable development of society by reasonable use and implement the natural biogeochemical cycles in technology. Based on the publications of the Russian and foreign scientists, as well as own research of the authors, in terms of being able to achieve harmony in sociobiotechnosphere, it is possible to suggest to use the potential of biological objects to solve environmental problems in all processes of coal deposits development. For example, at the stage of pre-production mining it is necessary to ensure a minimum level of primary adverse impact of technogenic activity on the upper part of the lithosphere. This required an analysis of geobotanic features of the territory, biochemical indicators of plants, material composition of overburden, and the removal and preservation of the fertile soil layer (if it is more than $10 \mathrm{~cm}$ thick). During mining operations, it is expedient to provide the integrated use of resources in the process of coal output. The sanitary-hygienic preservation of dump slope surfaces using hydroseeding is recommended, it prevents their dusting and transformation and degradation of natural systems. The quality of the environment must be monitored by means of biological monitoring in the area of mining and tailing dump, based on observation of organisms-bioindicators. The monitoring includes determining the technogenic loads using highly sensitive test systems, concentrations of pollutants in biological components in the present time period (micro-organisms, plants), the study of toxicants accumulation processes in the components of the natural environment. Reproduction works in technogenic bodies and remediation of ecosystems is carried out by agrochemical and agrotechnical recreation of soil fertility, 
using bacterial culture, mesofauna and soil-building fertilizers for soil enrichment.

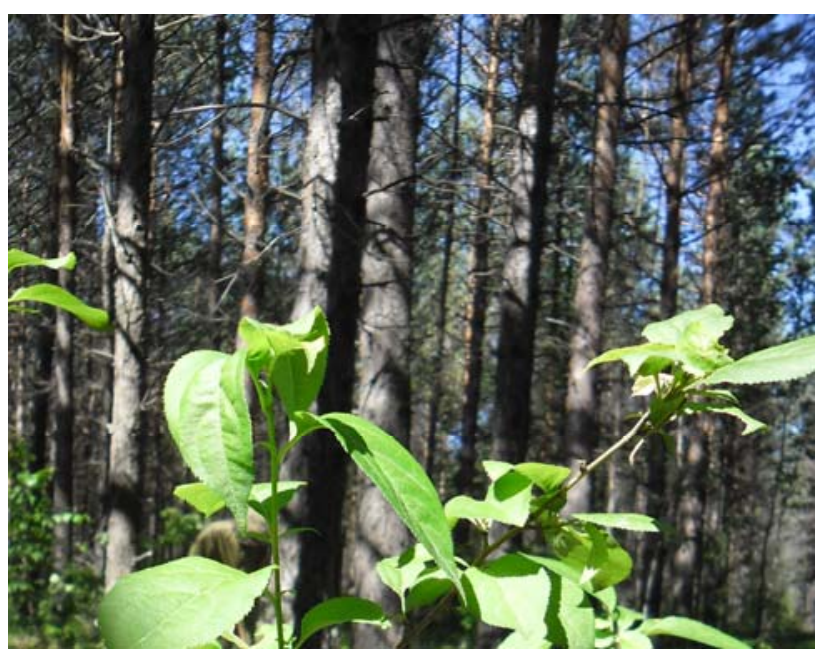

Figure 1. Pine afforestation at recultivated area (Amur Region, FEFD)

To prevent erosion processes on dumps the biological stabilization of ground surface is necessary using plants (perennial legume-grass mixtures).

Water reclamation is recommended to conduct reintroduction, moving the fish, plankton caught in the wild into newly created water bodies. To create new populations it is expedient to return the rare species of animals, plants to new technogenic systems. Industrial water treatment should be carried out using potential of biological systems. To return the land withdrawn during the development of coal deposits in the forest fund the forest restoration is necessary, involving forest replantation using bioremediation. The scientific novelty of the proposed measures is confirmed by Inventor's Certificate of the USSR and the Patents of the Russian Federation (Certificate of Authorship of the USSR [Krupskaya, Borisova, 1991], [Patents of Russian Federation, 2006 a, b, c, 2008, 2013, 2014, Krupskaya et al.].

\section{CONCLUSIONS}

Improving the legal framework and the introduction of fundamentally new technologies, in which the target application of biological systems and processes in the coal-mining industry used, as well as the development of problems of regional environment study in mining industry permit to ensure its social and environmental security, and give scientific credence of the strategic decisions on the sustainable development of mining areas in the Far Eastern Federal District of Russia.

\section{ACKNOWLEDGEMENTS}

The research work was supported by the Russian Science Foundation.

\section{REFERENCES}

[1] Vernadsky, V.I. 1978. Living matter, Moscow: Nauka, 357

[2] B.P Kolesnikov and L.V. Motorina, Methods of study of biogeocoenoses in technogene landscapes. Program and methods of technogene biogeocoenoses study, Moscow, Nauka, (1978) 5-21

[3] A.V. Nazarkina, L.T. Krupskaya, O.D. Arefieva, A.M. Derbentseva, V.G. Tregubova, L.P. Samchinskaya, P.F. Brovko, N.M. Kostenkov, A.I. Stepanova, N.G. Volobueva, A.V. Chernovalova.Technogenic transformation of soil characteristics of coal and mining complexes. FEFU Publishers (2012)143

[4] M. Akimov. Substantiation of technological processes efficiency ensuring higher quality of coal: Abstract of a thesis (Science Candidate - Engineering). Novocherkask (2002) 22.

[5] S.M. Romanov. Prospects and main problems of coal industry in Russia till 2020. Power Policy, No.2 (2007)55-63

[6] A.E. Kontorovich, V.V. Kuleshov. Strategy of coal industry development in Russia for the first ten years of $21^{\text {st }}$ century, "Geo", Siberian Branch of Russian Academy of Sciences (2003) 55.

[7] V.G. Kilimnik, G.G. Yakubson and N.V. Efimova. Social aspects of present coal industry in Russia. Mining: special magazine, No.3 (85). (2009) 16-18

[8] V.V. Bushuev, A.A. Troitsky. Predicted scenarios of innovative development of Russia till 2050. Energeticheskaya politika, No.2 (2006) 10-21.

[9] L.A.Puchkov, B.M. Vorobyev and Yu. F. Vasyuchkov. Future coalpower complexes. Moscow, Moscow State Mining University (2007). 245

[10] S.I. Shumakov. "Roadmap" of gradual transition to "pure coal" technologies till 2015-2020. Energeticheskaya politika (2006), No. 6 38-53.

[11] S. S. Timofeeva and O.V. Tyukalova. Ecological background of natural resources use: Educational book. Irkutsk, IrGTU (2007), 155.

[12] I. J. Higgins, D. J. Best and J. Jones Biotechnology Principles and applications. Moscow: Mir (1988), 480. 